\title{
AN EXAMINATION OF PEOPLES' AWARENESS AND RESPONSE TO ENVIRONMENTAL POLLUTION IN BENIN MUNICIPALITY, NIGERIA
}

\author{
Ikhile, C. I. \\ Department of Geography and Regional Planning, University of Benin, \\ PMB 1154, Benin City, Edo State, Nigeria
}

\begin{abstract}
An examination of peoples' awareness and response to environmental pollution in Benin Municipality, Nigeria was investigated. The questionnaire instrument was utilized in the survey. Two hundred and fifty questionnaires were administered at five randomly selected areas in five selected wards in May 2010. Analysis was carried out using simple percentages and frequency tables. The three most serious types of environmental pollution were listed as noise (35\%), air (26\%), water (20\%) and land (18\%). Street flood scored 59\%, flood pondages recorded $37 \%$, while river flood scored $4 \%$. The causes of flooding includes: insufficient drainage facilities to cope with excess rainfall (30\%), excessive rainfall (28\%), building along drainage pathways (30\%), while concreting of urban surfaces was $12 \%$. The concepts of environmental pollution, protection and preservation and the involvement of the respondents have not been fully understood by majority of the respondents.
\end{abstract}

Keywords: Environmental pollution, flooding, awareness, environmental protection and preservation.

\section{Introduction}

The coming generation, tends to face unprecedented environmental challenges and opportunities. Between 2010 and 2050, as world population grows by 3.7 billion, food production will need to double and industrial output and energy will probably triple worldwide and increase fivefold in developing countries (Personal Projection 2011). This growth brings with it the risk of appalling environmental decay and consequent pollution (Odjugo et al, 2002). The issues of the environment remain on top of the agenda of National Governments and International Development Agencies, and there is an interface between the environment and society. The nature of local and global environmental problems has undergone changes both in societal perceptions and policies formulated to tackle them. The interface between environment and the society is dynamic, and is brought into sharper focus with changes in human attitudes, values and behaviour (Chokor et al, 2007).

The idea of environmental awareness issues in society has been summarized in the guidelines of UNESCO-UNEP (2002) as follows:

a. Ecological foundations - dealing with the resources of the environment.

b. Human Environmental development - which embraces activities of humans that can affect the quality of the environment.

c. Environmental changes/impacts - highlighting issues and problems resulting from human interactions with the natural environment. Responses to natural disasters, rocks and minerals, development consequences, water pollution, threat to the ocean, atmosphere at risk, ecosystem under threat, people under threat, land under threat and agriculture under threat.

d. Sustainable development - relating to all management efforts aimed at keeping the environment supportive of development from generation to generation. 
This study examines peoples' awareness and response to issues of environmental pollution in Benin Municipality. The study therefore investigated:

i. society's level of awareness of environmental pollution in Benin Municipality,

ii. the major types of environmental pollution such as air, water, land and noise,

iii. the causes, effects, and possible solutions to these major environmental pollution problems,

iv. the problem of flooding as a cause of environmental pollution in the Benin Municipality, with reference to the causes, effects and possible solutions, and

v. investigates the ways in which the society can be involved in environmental protection and preservation.

\section{The study area}

\section{Location and Extent}

The study area is Benin City, the capital of Edo State, Nigeria (Figure 1). Benin City is located within longitude $5^{0} 35^{\prime} \mathrm{E}$ and $5^{\circ} 41^{\prime} \mathrm{E}$ and latitude $6^{\circ} 26^{\prime} \mathrm{N}$ and $6^{0} 31^{\prime} \mathrm{N}$. It comprises the urbanized parts of fo local government areas of Oredo, Egor, Ikpoba Okha and Uhunmwunode. It is a nodal route town that links the North through BeninAuchi-Okene Road, South through Benin-Lagos Road, East through Benin-Asaba Road and Western parts of the country through Benin ifon Road. It is both a commercial and industrial town with 15 daily markets. Benin City is characterized by tropical climate with rainfall all year round. It is found in the equatorial climate belt (Koppen's Aw zone) with summer rains and winter dryness. Though there is hardly any month without an element of rainfall, rain concentrates within the months of April and October (rainy season) while dry season prevails between November and March. The mean annual rainfall is constantly above $2000 \mathrm{~mm}$, with relative humidity above $70 \%$. Temperature is high throughout the year, with an annual temperature of $28^{\circ} \mathrm{C}$ (Ikhile et al, 2003). In order to acquire comprehensive baseline information of people's awareness and response to environmental pollution in the municipality, five sampling sites were carefully selected to represent the quarters in the municipality with high level of environmental pollution. These sites represent the core areas of the municipality with perceived high pollution status (Table 1). The monitoring sites were geo-referenced using a GARMIN GPS MAP 765 chart plotting receiver.

Table 1 Environmental pollution study sites, descriptions and coordinates

\begin{tabular}{|c|c|}
\hline $\mathrm{S} / \mathrm{N}$ & Location description \\
\hline 1. & 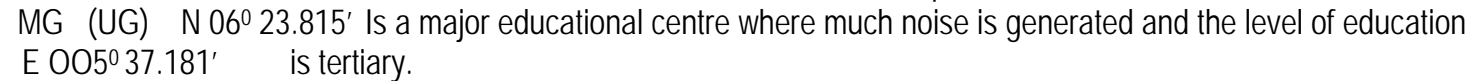 \\
\hline 2. & $\begin{array}{l}\text { US (P \& G) N } 06^{0} 21.768^{\prime} \text { Uselu area with lots of gabbage, high traffic volume and much noise. Is a market centre } \\
\text { E } 005^{\circ} 37.116^{\prime} \text { and liable to flooding. }\end{array}$ \\
\hline 3. & $\begin{array}{l}\text { TM (RR) N } 06^{0} 20.440^{\prime} \text { major residential area, close to city centre. Lots of noise and air pollution generation. } \\
\text { E OO50 } 37.339^{\prime}\end{array}$ \\
\hline 4. & $\begin{array}{l}\text { NB (NB) N } 06^{\circ} 20.939^{\prime} \text { Flood prone environment. Big market centre. Evidence of all forms of pollution. } \\
\text { Subjected } \\
\text { E OO5 } 37.925^{\prime} \quad \text { to flooding. }\end{array}$ \\
\hline 5. & $\begin{array}{l}\text { IH (AP) N } 06^{0} 21.003^{\prime} \text { Big Market area with lots of gabbage, noise and air pollution. Affected by seasonal } \\
\text { E OO5 } 39.643^{\prime} \text { flooding. }\end{array}$ \\
\hline
\end{tabular}

The areas covered by this study are indicated in Figure 1 to include: (1) Ugbowo (MG) (2) Uselu (P\&G) (3) Textile Mill Road (RR) (4) New Benin (NB) and (5) Ikpoba Hill 
(AP). These areas represent the core areas of Benin Municipality. Moreover, Ugbowo, Uselu and Textile Mill Road are in Egor L.G.A, while New Benin is in Oredo L.G.A. and Ikpoba Hill is in Ikpoba Okha Local Government Areas respectively. These are three out of the four Local Government Areas that make up Benin Municipality.

\section{Population}

The National Population Commission (NPC, 2009) gave the 2006 population figure for the three Local Government Areas out of the four under investigation that make up the Benin Municipality as 1, 086,882. Egor LGA has a total figure 340, 278, Ikpoba-Okha, 372,080 and Oredo is 374,515. Edo State falls between medium and low average population growth rafes.

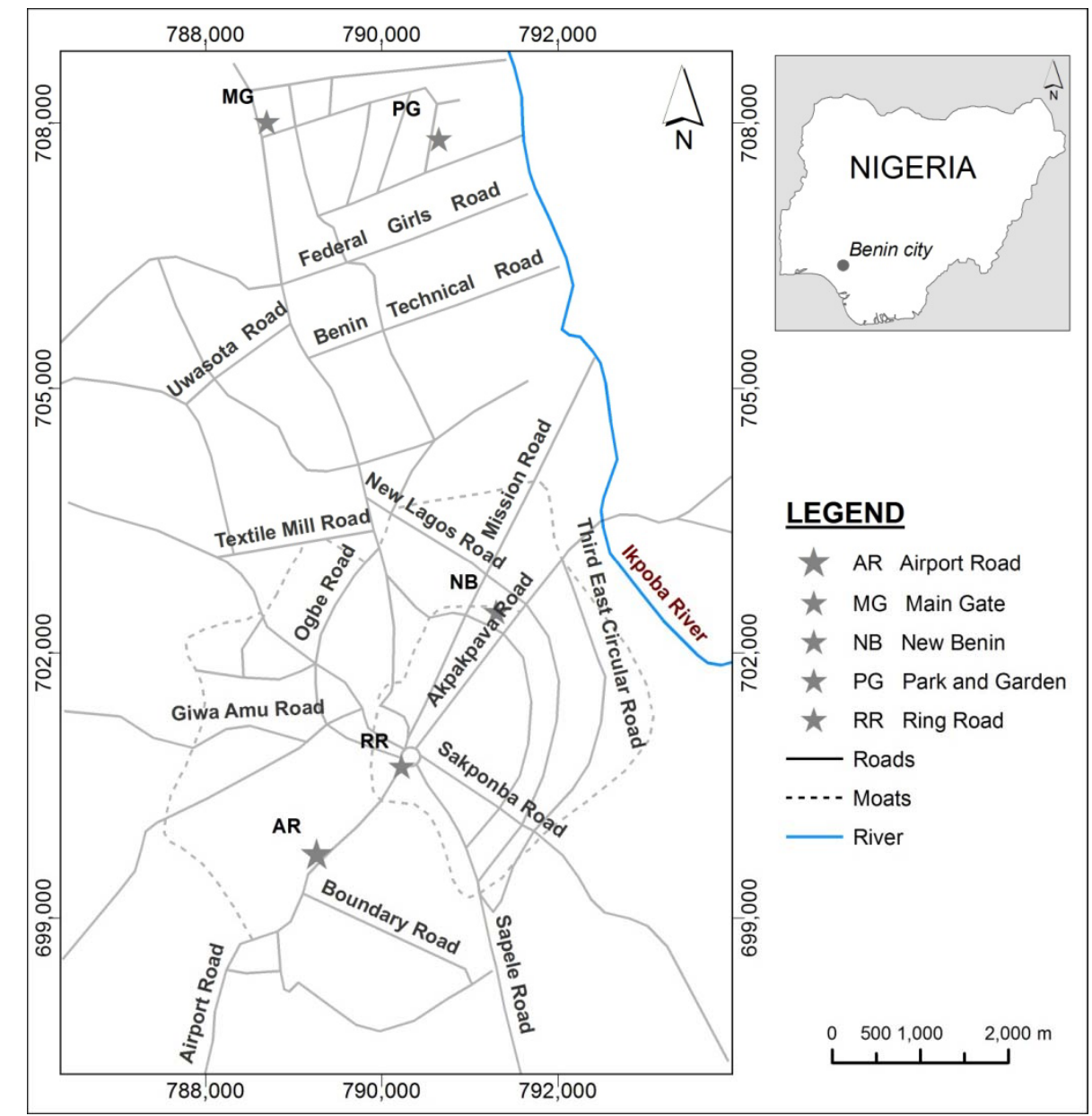

Figure 1. GIS base-map of Benin Municipality showing sampling sites

\section{Landuse}

The landuse types include vegetation, agriculture (agro-forestry such as plantations and other forests, arable cultivation denoted as cultivated lands), roads, residential, markets and schools. Almost all the ethnic groups that live in the Municipality are engage in arable farming. The Bini tribe however forms about $90 \%$ of the farming population. About $58 \%$ of the Municipality are traders (Figure 3) while about $30 \%$ engage in education at the different levels of education (Figure 3). The built-up area of Benin City as at 1965 was about 2,500 hectares. By 1979, the total built-up area had grown to 3,000 hectares, excluding vacant plots. (Ikhuoria, 1994). According to him, 
changes in the city's radius gave rise to geometric increase in its area. By 1987, the areal extent had grown to 64,500 hectares, while by 2000 , it was 80,400 hectares.

Other settlements in the Municipality included very many villages of different sizes, most of which formerly ranged between $5-10 \mathrm{~km}$ distance have merged with the Benin metropolis. Examples are Aduwawa, Ekosodin, Isiohor, Ugbekun, Oliha amongst others. The number of roads has increased and the original tropical rainforest vegetation is now a more open type of guinea savanna vegetation. The many rubber plantations that existed in the 1970s have been converted to built-up areas and farmlands. These changes are accompanied by the rapid rate of population growth in the Municipality (Ikhile et al, 2007).

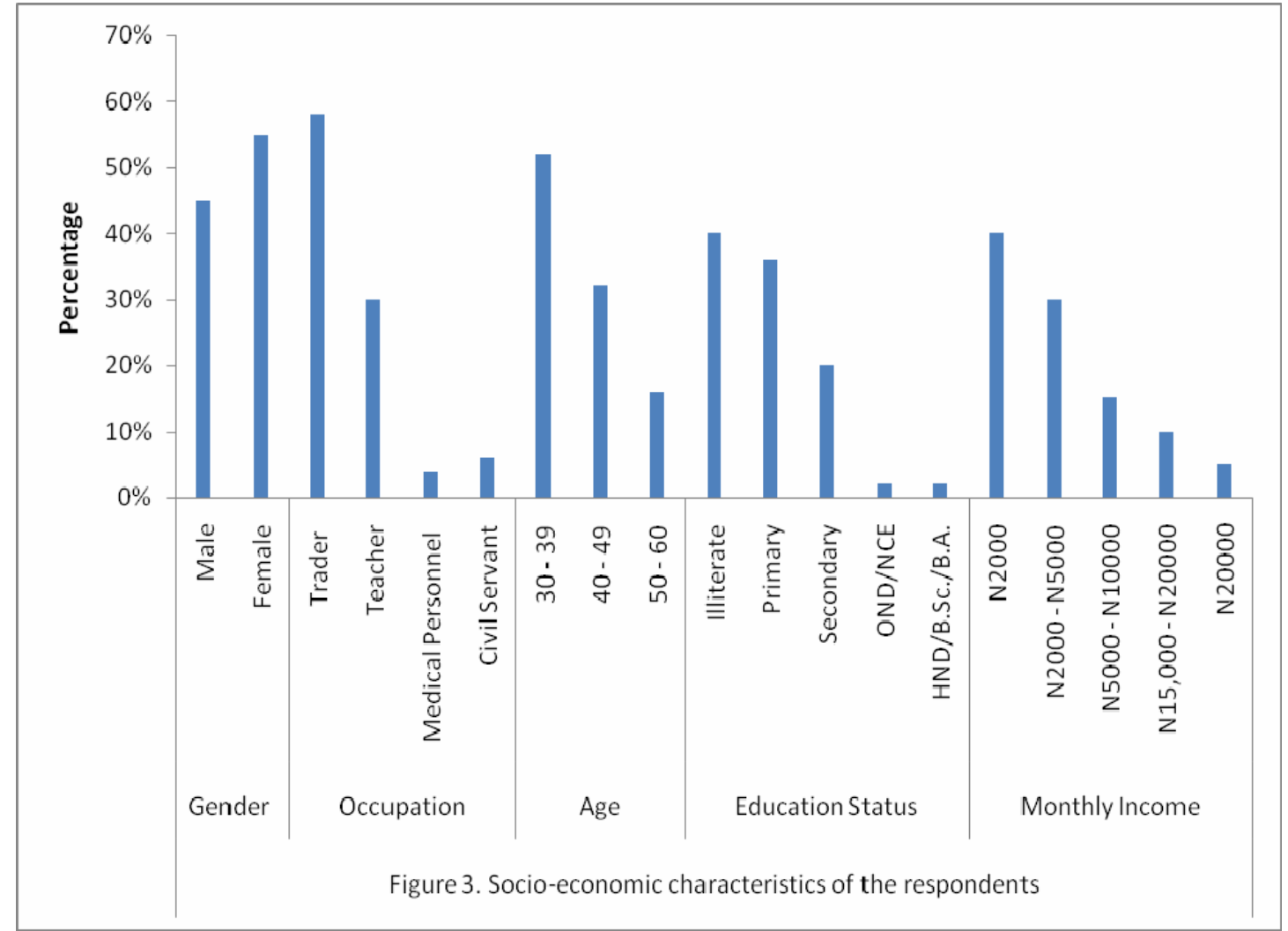

Figure 3. Socio-economic characteristics of the respondents

\section{Method of study}

The study is premised on 12 out of the 21 neighbourhoods in Benin Municipality adopted by Obot (2006). These 12 neighbourhoods cut across the major wards investigated in the three Local Government Areas in the Municipality. A field survey was conducted to examine peoples' awareness of and response to Environmental Pollution in Benin Municipality in these areas.

Two hundred and fifty (250) questionnaires were administered at the randomly selected five out of the thirty-two wards at the rate of fifty (50) questionnaires per area. The simple random sampling technique was utilized to select five streets in each area. In each street every fifth house was chosen and the questionnaires were administered to any adult member of the compound. Ten questionnaires were administered in each street in these areas. The data collected was grouped under (i) Socio-economic characteristics of respondents which included age, educational status, occupation and level of income. (ii) Level of awareness of environmental pollution problems. This included definition, types, causes and effects. (iii) The problem of flooding in the 
Municipality which included types, causes, areas most proned, effects and possible solutions. (iv) Response of the public to Environmental Protectioon and Preservation in the Municipality was lastly dealt with. Results obtained were analysized using simple percentages and frequency tables. Results are presented in Tables $2-5$ and Figures 3-7.

\section{Results and Discussion}

\section{Relationship Between Socio-Economic Characteristics and Percentage of Awareness Level of the Respondents in Benin Municipality}

Information on the Socio-Economic Characteristics and the awareness of Environmental Pollution Problems of Respondents in Benin Municipality is indicated on Figure 3. The research revealed that $45 \%$ of the male respondents are aware of environmental problems while $55 \%$ of the female are also aware and $55 \% / 45 \%$ of the male/female respondents are not aware. The ages of these respondents ranged between $30-39$ years $(52 \%)$ and $40-49$ years $(32 \%)$ while $50-59$ years $(16 \%)$ for both male and females. The educational status of the respondents showed that $40 \%$ of the population had no formal education, $36 \%$ had primary education, and $20 \%$ had secondary education while $5 \%$ had HND/B. Sc/B.A. Their level of awareness of environmental problems is in the reverse order as it is seen that the more educated the people are the more conscious they become of environmental issues. For occupation of the respondents, $58 \%$ are traders, 30\% are teachers in primary and secondary schools, $4 \%$ are medical personnel, $6 \%$ are Civil Servants while $2 \%$ are University staff. From previous knowledge of the respondents, the reversal is also the case in matter of awareness of environmental problems. This argument holds also for the income level brackets which is seen to be $40 \%$ that fall into less than $\mathrm{N} 2,000$ monthly income bracket, $30 \%$ earned between $\mathrm{N} 2,000$ - N5,000 monthly, $15 \%$ earned between N5,000 - N10,000 monthly, $10 \%$ earned between N10,000 - N20,000 monthly while $5 \%$ earned more than N20,000 monthly. Education and income level seen to agree with each other as the more educated people earn higher income.

\section{Level of Awareness of Environmental Pollution in Benin Municipality}

Information on the level of awareness of Environmental Pollution in Benin Municipality of all the respondents is indicated in Tables 2-5 and Figures 4-5.From the analysis of the questionnaire survey on the level of awareness of environmental pollution, $40 \%$ of the sampled population agreed that environmental pollution is anything that destroys the purity of the environment; $25 \%$ said that environmental pollution is anything that makes the water unfit for human use; $22 \%$ said that releasing plenty of smoke into the air, and $13 \%$ held that playing loud music constitutes environmental pollution (Figure 4a). For the type of pollution prevalent in Benin Municipality, $24 \%$ of the respondents indicated air pollution while $26 \%$ indicated water pollution. $27 \%$ indicated soil pollution, and $22 \%$ indicated noise pollution. They are all equally informal about the pollution types in Benin Municipality. Land/soil pollution ranked highest, followed by water, air and then noise. It would have been ideal if all the respondents gave $100 \%$ each for all the pollution types. This is an indication of low level of awareness about environmental issues in Benin Municipality. Air pollution is said to be caused mainly by vehicular emission in Benin Municipality, as evidenced by $51 \%$ response, while $22 \%$ indicated emission from power house/generators; $19 \%$ said it is emission from industries; $5 \%$ said the use of pesticides/chemicals contributes to air pollution and $0.5 \%$ attributed it to gas flaring emissions. Some others indicated that 
poultry houses, bush burning, and refuse burning, contributed to air pollution. For the causes of water pollution, oil spillage accounted for $40 \%$, domestic waste disposal to rivers was $50 \%$, industrial effluent discharge was $30 \%$, discharge for septic tanks was $14 \%$, the use of Gammalin 20 to kill fishes was

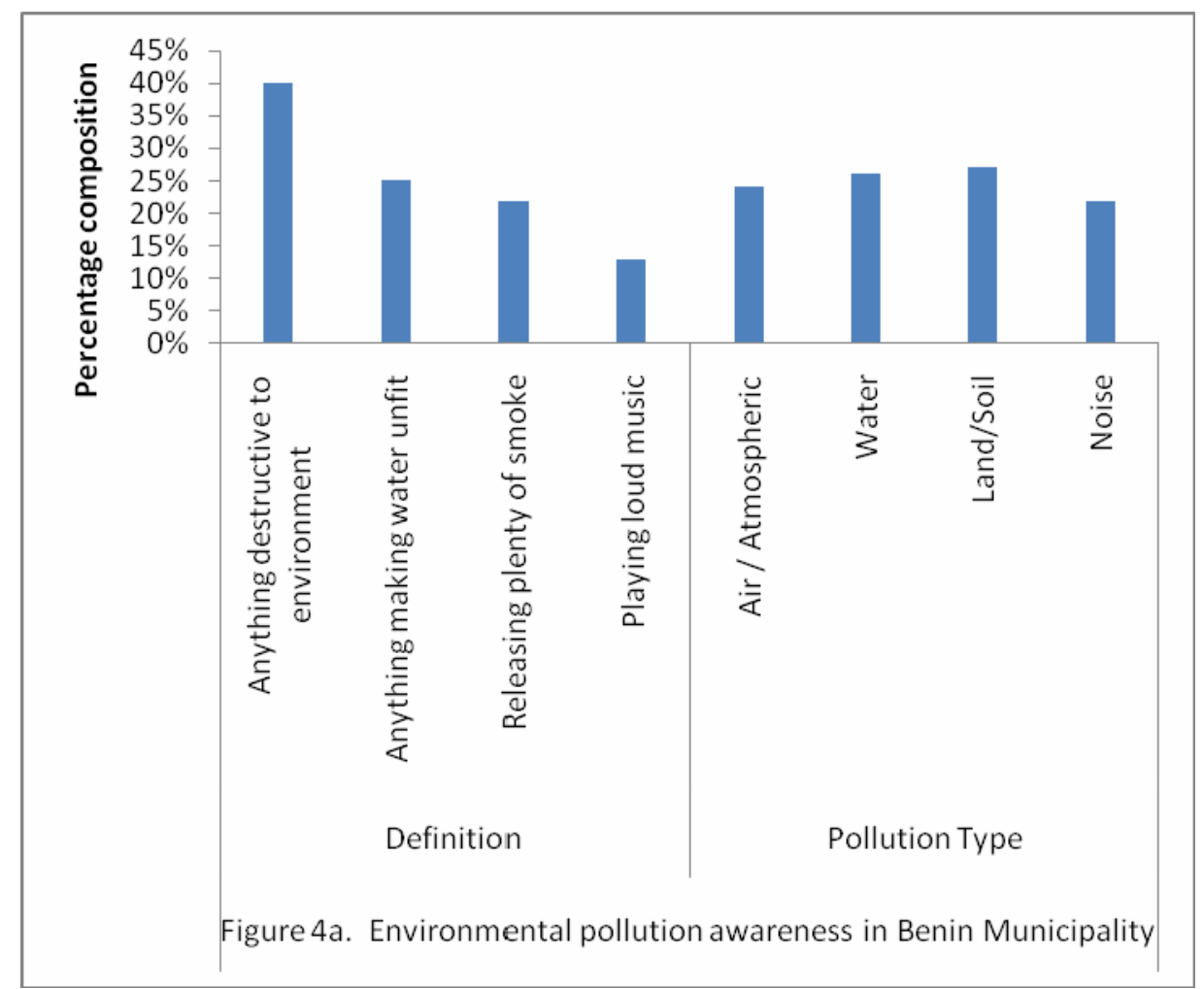

Figure 4a. Environmental pollution awareness in Benin Municipality.

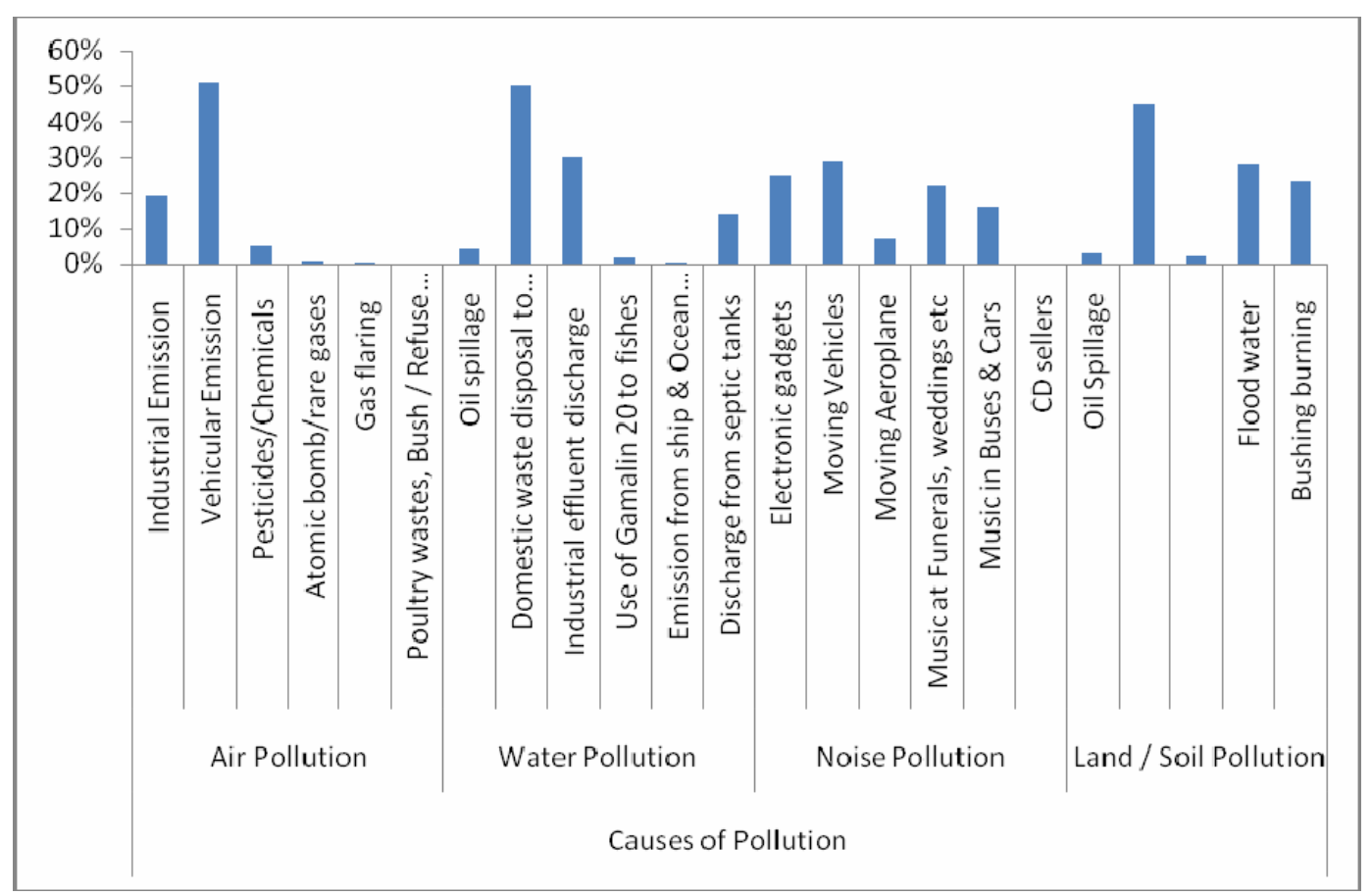

Figure 4b. Awareness of types environmental pollution in Benin Municipality 


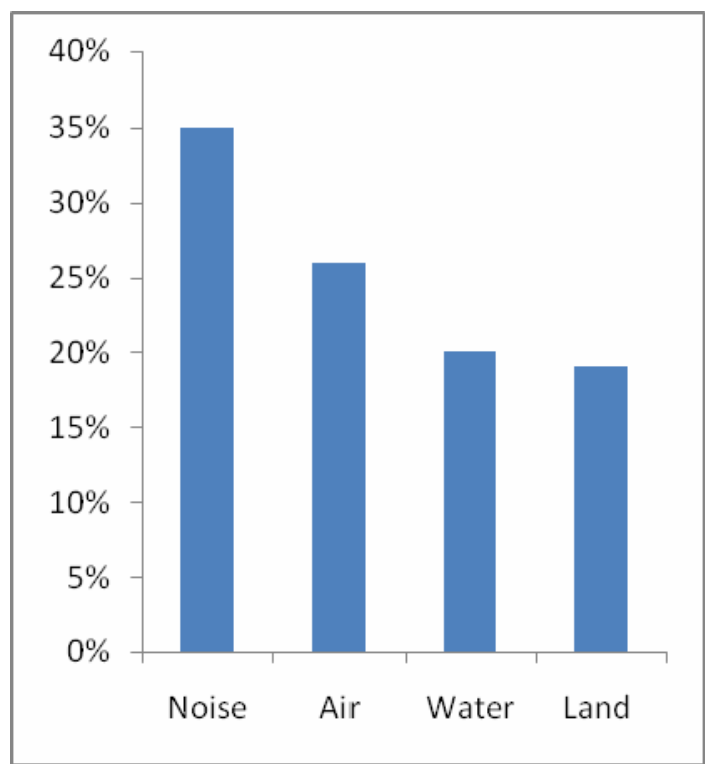

Figure 5. The order of seriousness of environmental pollution

$1.5 \%$, while emission from ship and sea vessels was $0.5 \%$. Some others indicated flooding as a cause. For the causes of noise pollution, $25 \%$ said it is due to the use of electronic gadgets, while $29 \%$ held that moving vehicles generate more noise in the Municipality. Moving aeroplane is $7 \%$, Music at Funeral functions, weddings etc $22 \%$, Music in buses and cars $16 \%$. Land/soil pollution is said to be caused by oil spillage $(3 \%)$, indiscriminate dumping of refuse $(45 \%)$, and application of fertilizer $(2 \%)$, flood water $(28 \%)$, and bush burning (23\%) (Figure $4 \mathrm{~b})$. On the localities of most serious environmental pollution, almost the whole Metropolis was cited. Such localities included Uselu, Ikpoba hill, New Benin, Adolor, Uwelu, Ring Road, Oliha, Murtala Mohammed Way, Textile Mill Road, Aduwawa, Ogida, Ugbor, Sapele Road, Queen Ede, Oluku, Upper Mission, Five Junction, Iyaro, Ogbesan, Trade Fair, and Teachers' House, in that order (Table 2). The three most serious types of environmental pollution were listed as noise (35\%), air (26\%), and water as $20 \%$ and land as $19 \%$. (Figure 5). The effect of air pollution according to the survey includes difficulty in breathing as the most serious, followed by heart problem, poor visibility, catarrh, mental illness, headache, cough, ozone depletion, eye problem, and bad odour (Table 3). The effects of noise pollution were given as effect on hearing as the most serious problem, deafness, lack of concentration, distraction, discomfort, restlessness, stress, and slow thinking (Table 4). The effects of water pollution was given as causing cholera, other water-borne diseases

Table 2. Key to perceived areas of most serious environmental pollution in Benin Municipality in descending order.
1 Uselu
2 Ikpoba hill
3. New Benin
4. Adolor
5. Uwelu
6. Ring Road
7. Oliha
9. Textile Mill Road 10 Aduwawa
11. Ogida
8. Murtala Mohammed Way
13 Sapele Road
14 Queen Ede
15 Oluku
17 Five Junction
18 lyaro
19 Ogbesan
12 Ugbor
16 Upper Mission
20 Trade Fair
21 Teachers' House. 
Table 3. Key to perceived effects of air pollution in Benin Municipality in descending order.

1 Difficulty in breathing. 2. Heart problem. 3. Poor visibility. 4. Catarrh.

5. Mental illness. 6. Headache. 7. Cough. $\quad$ 8. Ozone depletion.

9. Eye problem 10. Bad odour.

Table 4. Key to perceived effects of noise pollution in Benin Municipality in descending order.

1. Difficulty in hearing. 2 Deafness 3. Lack of concentration. 4. Distraction.

5. Discomfort. 6. Restlessness. 7. Stress. 8. Slow thinking.

Table 5. Key to perceived effects of water pollution in Benin Municipality in descending order.

1. Cholera other water borne diseases 2. Loss of aquatic life. 3. Effects on plants.

4. Shortage of water. 5. Loss of life 6. Tapeworm. 7. River blindness.

Loss of aquatic life, effects on plants, shortage of water, loss of life, tapeworm, and river blindness (Table 5). There is a statistically significant relationship between the level of education and awareness of environmental pollution issues at $5 \%$ confidence level.

Similarly there is a significant correlation at $1 \%$ confidence limit between level of education and occupation in relation to the population's involvement in environmental protection and preservation.

\section{Flooding Pollution causes in Benin Municipality}

Flooding has become a major Environmental problem in Benin Municipality (Ikhile, et al 2009a).The treatment of Environmental pollution problem in Benin Municipality will not be complete without a discussion of flooding problem. Flooding leaves behind a lot of trash when the uncontrolled water recedes and has therefore become a menace in the metropolis. Results of this analysis are presented in Figures 6-7. From the 


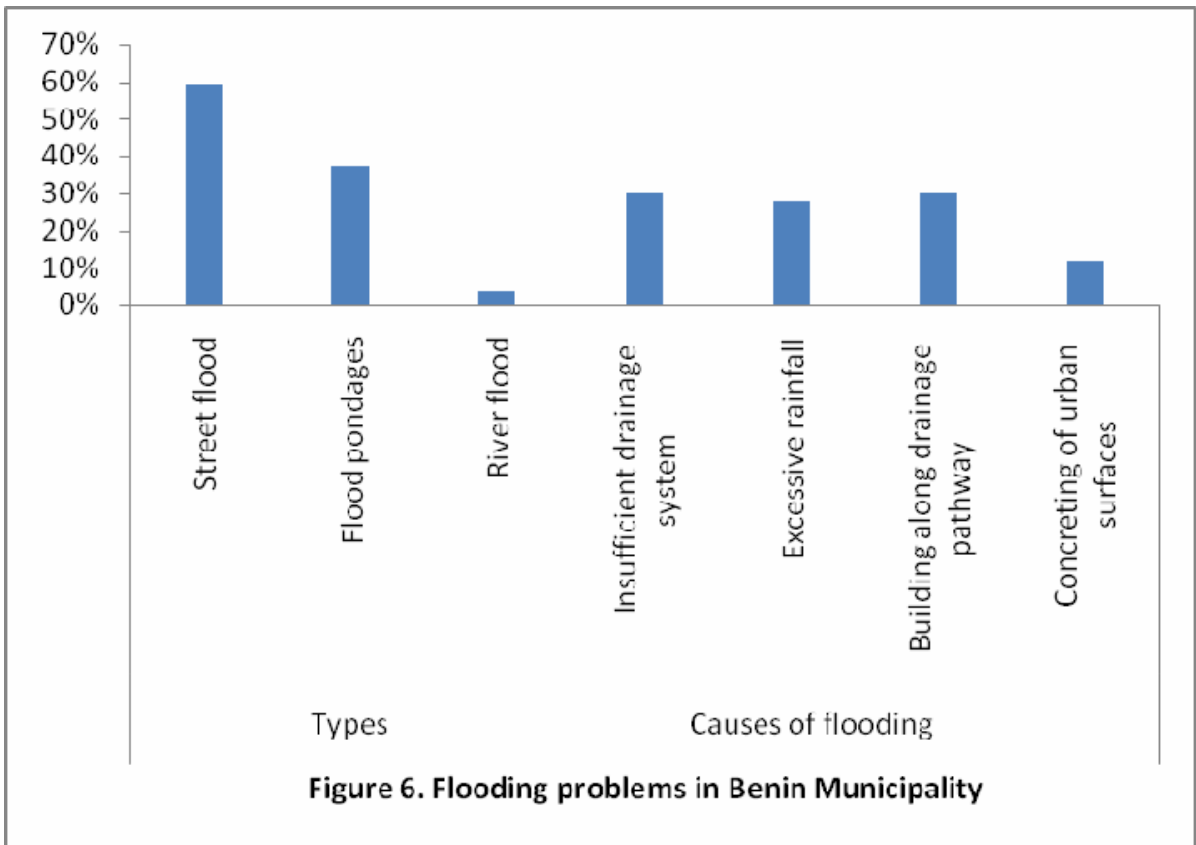

Figure 6. Flooding problems in Benin Municipality

Questionnaire analysis, street flood is the most important with a score of $59 \%$, flood pondages is the next with $37 \%$, and river flood with $4 \%$. The causes of flooding in the Benin Municipality includes: insufficient drainage system to cope with excess rainfall $(30 \%)$, excessive rainfall $(28 \%)$, building along drainage pathway $(30 \%)$, while concreting of urban surfaces was $12 \%$ (Figure 6). The areas/streets prone to flooding in Benin City, included Five Junction, Adolor Road Junction, Uselu, Uwasota, Ugbowo, Wire Road, Upper Lawani, Aduwawa, Ekosodin, Lucky Way, Lagos Street, Trade Fair Area, Uwelu, Siluko Road, Upper Mission, Upper Sokponba, Useh-Egor, Okhoro, Erhumwunse, Medical Stores Road, Ogiso, Ikpoba Hill, Ewa Road, Evbareke,, Textile Mill Road, Owina, New Lagos Road, Evbotubu, Agbor Road, and EDPA. This is an indication of the fact that more than $80 \%$ of the Municipality is suffering from serious flood problems that can last for days (Ikhile et al, 2009a). The negative effects of flooding according to the survey includes destruction of household items, rendering inhabitants homeless, restriction of accessibility, land rendered unsuitable for cropping, breeding of mosquitoes, bad roads, poverty, hunger, traffic jams, accidents, business obstruction, loss of lives, damage to buildings, and consequent water erosion. This investigation is in line with an earlier investigation in Benin River Basin (Ikhile et al, 2009a).When respondents were asked if it were possible to completely eradicate flooding in the City, $78 \%$ said yes, while $22 \%$ said no. When asked who should be responsible for the removal of floods from our streets, $8 \%$ of respondents said that it should be the responsibility of students, $24 \%$ said that individuals should be involved, while $14 \%$ said that families should be involved. While $27 \%$ said that it should be the responsibility of people in each street, $15 \%$ said that it should be the people in each quarter. $12 \%$ believed it should be the people in each compound. At the government level, $33 \%$ said it is the responsibility of the Local government while $45 \%$ said it was the responsibility of the State Government. $22 \%$ said it was the responsibility of the Federal Government to control flooding in the Metropolis (Figure 7). The above views are in consonance with Jimoh (2000) and Isalar (2005) who hold that it should be the 
concerted of all to make the environment safe and salvage man and his environment from eminent destruction.

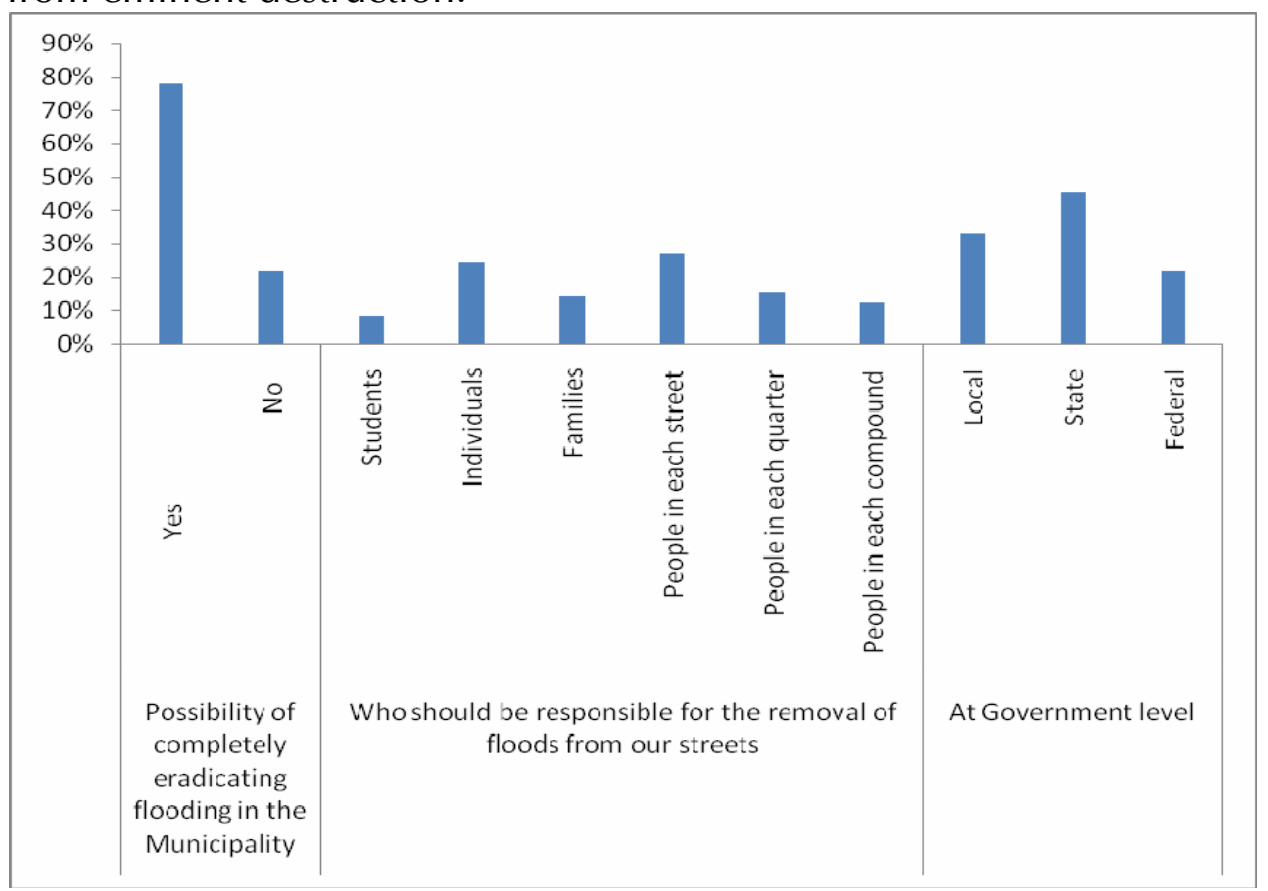

Figure 7. Eradicating flooding in the Municipality

\section{People's Involvement in Environmental Protection and Preservation}

Information on People's Response to Environmental Protection and Preservation is on Figure 8.On the current measures (demolition of illegal structures and rebuilding of roads and drainage facilities in Benin Municipality) adopted by the Edo State Governor, Comrade Adams Oshiomole, 90\% agreed that the measures are relevant, while 10\% said they were irrelevant. When asked those attitudes that people must change/cultivate in order to care for the environment, $30 \%$ of the respondents indicated that the people must always keep their environment clean; $5 \%$ said that people should belong to environmental conservation clubs in schools; $36 \%$ said that people should partake in the regular environmental sanitation exercise embarked upon by the State Government; $15 \%$ held that people should stop cutting down tree; while $7 \%$ indicated that planning to have a small family size is important. The respondents agree that a healthy environment is an inheritance to be passed on from generation to generation. This was the view expressed by $99 \%$ of the respondents, while $1 \%$ said it is not necessarily so. On the issue of ways people can take part in keeping their surroundings clean, different suggestions were made. 


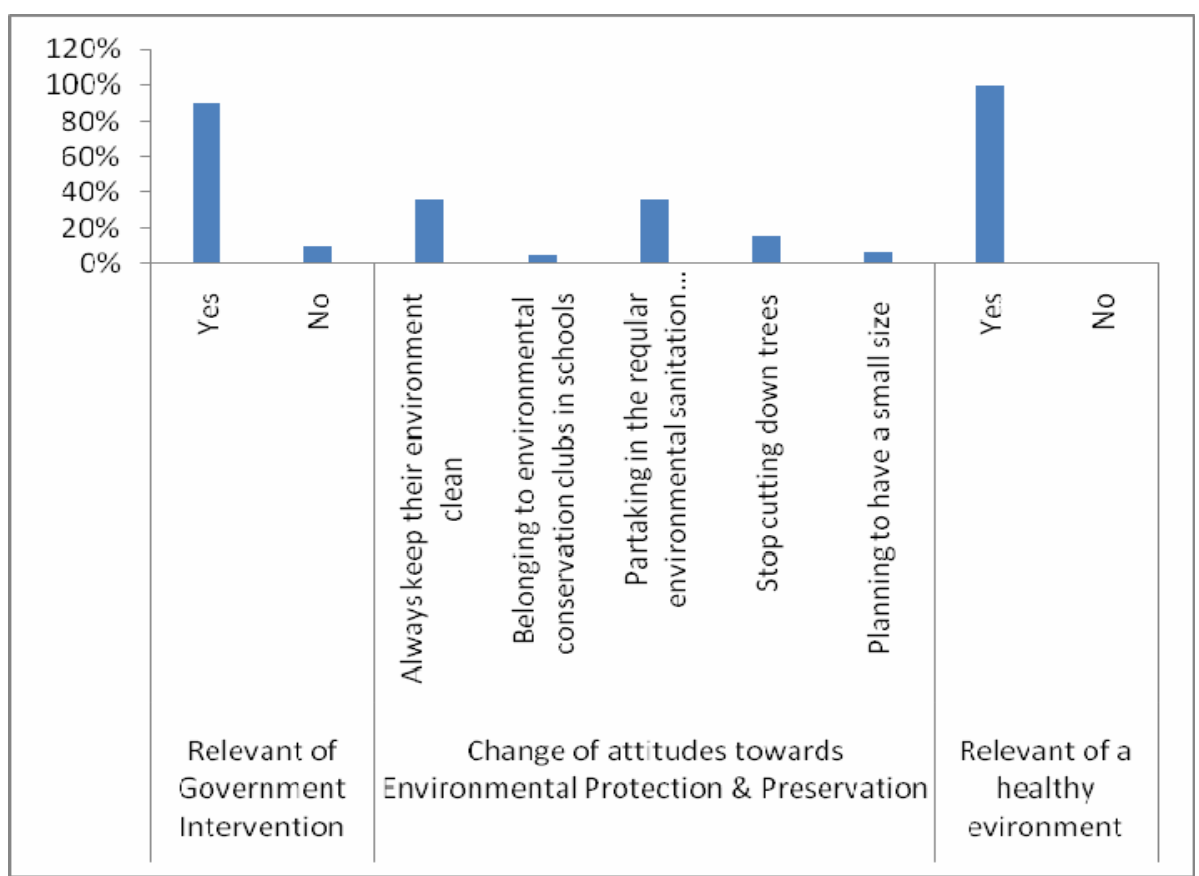

Figure 8. People involment in Environmental Protection and Preservation.

These included regular environmental sanitation, provision of waste disposal bins, regular collection of waste and proper disposal of the waste collected, clearing the drainage systems, abiding by environmental laws, payment of tax to enable government provide facilities to maintain a good environment. Some said that indiscriminate dumping of refuse in the environment should stop. Also, bush clearing; burning and indiscriminate felling of trees should stop. Daily sweeping of the environment, cleanliness and personal hygiene were advocated (Figure 8).

\section{Conclusion}

It is concluded that the concept of environmental pollution has not been fully grasped by the respondents let alone their personal and individual involvement in environmental protection and preservation. Their knowledge of the various types of environmental pollution in the Municipality is low. The causes of air, water and land pollution is not too clear to the populace as indicated in their responses. The causes of air, water and land pollution are not equally well grasped by the respondents. The respondents held that the three most serious types of pollution in the Benin Municipality are noise, air, water, and land in that order. Given the current level of environmental pollution eradication, the respondents believed that the City can be rid of all forms of pollution, though they are not so sure if it is really possible to achieve total eradication. The awareness and concern/conviction of the responsiveness of the society to environmental issues in Benin Municipality is not appreciable. It was concluded that the society should be made to be more involved and conscious of a clean environment. Also the three tiers of government should embark more on campaigns for a clean environment. Stronger environmental awareness campaigns must be constantly carried out by the relevant agencies concerned with environmental protection and preservation. The existing environmental laws should be enforced continuously. Collective responsiveness for a clean environment should go on being advocated. The results obtained in this study are comparable with Ikhile (1995) in which she observed that the general level of awareness of students on general 
environmental issues was found to be average. A period of fifteen (15) years does not seem to have made any difference on the awareness level on Environmental pollution in Benin Municipality.

\section{References}

Chokor, B. A. and Ozo, A. O. (2007): "Environment and society in Nigeria. Environment and Behaviour Association of Nigeria (EBAN)", University of Lagos, Nigeria.

Ikhile, C. I. (1995): Student Responsiveness to Environmental Education (EE) in Benin Municipality with Regards to Environmental Pollution. PGDE Thesis submitted to Institute of Education, University of Benin, Benin City, Nigeria.

Ikhile, C. I. and Lekan O. (2007): Application of Geographic Information System

(GIS) to the study of landuse changes in the Osse-Ossiomo River Basin, Edo State, Nigeria in Proceedings of IAHS, UK.

Ikhile, C. I. and Ikhile, G. U. (2003), Effects of climate change on irrigation activities: A case study of the Benin - Owena river Basin IAHS Publ 281, 287 - 293.

Ikhile, C. I. and Aifesehi, P. E. (2009a): "Climate Change Impacts: A Case Study of Flooding in Benin River Basin, Nigeria". Ikogho-A Mulit-Disciplinary Journal, Port Harcourt, Nigeria.

Ikhuoria, I. A. (1994): A study of the Academic Cartography in Nigeria, in: Ikhuoria, Isi

A. (ed), Cartography and Rural Development in Nigeria, Nigeria Cartographic Association, Benin City. pp.1-17.

Isalar, I. C. (2005): The Contribution of Technology to Environmental Pollution and Global Warming, Paper presented at the 2005 Conference of the Environmental and Behaviour Association of Nigeria, University of Benin, Benin City, Nigeria.

Jimoh, H. I. (2000):'Man-Environment Interactions'in Jimoh, H.I. and Ifabiyi, I. P. (ed) Contemporary Issues in Environmental Studies, Haytee Press and Publ. Co Ltd, Ilorin, Kwara State, Nigeria.

NPC (2009), Nigerian National Population Commission Census, Federal Republic of Nigeria Official Gazette.

Obot, I. S. (2006): An Evaluation of Development Control on Landuses ih Benin City, B. Sc Thesis, University of Benin, Benib City, Nigeria.

Odjugo, P. A. O. and Ikhile, C. I. (2002): "Seasonal Variation and Environmental Impacts of Polyethylene (Cellophane) Generation and Disposal in Benin City, Nigeria". Benin

Journal of Social Sciences (BJSS), Vols 10 and 11, Nos 1\&2, Benin City, pp12-21.

Sanyu, R. O. and Sumiko, A. P. (1994): Draft Report on Study of the National Water Resources Master Plan, Federal Ministry of Water Resources Rural Development (FMWRRD) Abuja, Nigeria

UNESCO-UNEP (2002): "Procedure for Developing an Environmental Education Curriculum: A Discussion Guide for UNESCO Training Seminars on Environmental Education". Prepared by Hungerford, H.R. and Peyton R.B. Paris, UNESCO-UNEP international Environmental Education Programme, 2002.

World Development Report (2002): Development and the Environment, The World Bank, Oxford. 